tal na produção de uma tradição de pensamento engajada com a luta pela emancipação e autodeterminação de coletivos "não modernos" ou "minoritários", tradição que teria impacto no trabalho de autores como Darcy Ribeiro e Florestan Fernandes, entre outros. "Curt Nimuendaju percorreu o Brasil e registrou de maneira ímpar a riqueza e a complexidade dos modos de viver e de pensar de diversos coletivos indígenas", conta Matos.

Quando, já nos anos 1990, Tânia Stolze Lima e Eduardo Viveiros de Castro elaboram o conceito de perspectivismo amerindio, a antropologia brasileira entra em um debate horizontal com o melhor que havia se produzido na antropologia inglesa ou francesa desde a década de 1980: "Vemos novamente como o diálogo cuidadoso com as populações indígenas brasileiras pode lançar nossa produção científica a uma posição de vanguarda na produção acadêmica mundial", constata o antropólogo. "O que é interessante observar, nesse caso, é que o conceito de perspectivismo, assim como o que nos traz a obra de Nimuendaju, diz respeito justamente às formações filosóficas indígenas que Oswald de Andrade tematizou sob a ideia de antropofagia: trata-se de uma abertura à diferença, e da consciência de que a diferença (ou a sociobiodiversidade) é imprescindível para uma vida que valha a pena ser vivida. Daí o famoso dizer do Manifesto antropófago: 'só me interessa o que não é meu'", finaliza Matos.

Mariana Garcia de Castro Alves

\title{
ECONOMIA
}

\section{ALÉM DOS SABERES E FAZERES: O IMPACTO SOCIAL E ECONÔMICO DA INDÚSTRIA CRIATIVA}

Em novembro de 2019 a Organização das Nações Unidas (ONU) declarou 2021 como Ano Internacional da Economia Criativa para o Desenvolvimento Sustentável. A proposta reconhece a necessidade de promover um crescimento econômico inclusivo e sustentado, promover a inovação e oferecer oportunidades, benefícios e empoderamento para todos e respeito por todos os direitos humanos e a necessidade contínua de apoiar países em desenvolvimento e países com economias em transição para diversificar a produção e as exportaçôes, inclusive em novas áreas de crescimento sustentável, inclusive indústrias criativas.

No Brasil, a economia criativa vem crescendo anualmente, com perspectiva de girar mais de US\$ 40 bilhôes até 2021, com impacto na vida de mais de 835 mil profissionais e inclusão de diferentes grupos sociais. A Federação das Indústrias do Estado do Rio de Janeiro (Firjan), que elabora o Mapeamento da Indústria Criativa no Brasil, divide o setor em quatro grandes áreas: consumo (design, arquitetura, moda e publicidade \& marketing), mídias (editorial e audiovisual), cultura (patrimônio e artes, música, artes cênicas e expressões culturais) e tecnologia ( $\& \& D$, biotecnologia e TIC). De acordo com o Mapeamento de 2019, o consumo $(43,8 \%)$ e a tecnologia $(37,1 \%)$ responderam por aproximadamente $80 \%$ dos trabalhadores criativos no Brasil. Acelerado pelas novas tecnologias na década passada, a economia criativa abriu espaço para a geração de novas ideias e comportamentos de criação e, consequentemente, para a forma de consumirmos produtos e serviços. Hoje, o impacto da economia criativa na atividade econômica brasileira é extremamente relevante. $\mathrm{O}$ número de novos empregos é crescente: entre 2015 e 2017, cerca de 1,7 milhão de postos de trabalho tradicionais foram perdidos no país. Nesse mesmo período, mais de 25 mil novas vagas para dez profissões dentro da economia criativa foram criadas. A expectativa é que a economia criativa brasileira atinja US\$ 43,7 bilhões até 2021.

INCLUSÃo Para Sâmia Torresini, diretora da Artesano, que comercializa mel artesanal, esse nicho da economia é importante por valorizar o trabalho manual, alavancar o consumo consciente e dar espaço para diferentes grupos e minorias. Já Karina Rossi, uma das sócias da Rede Manual, grupo 

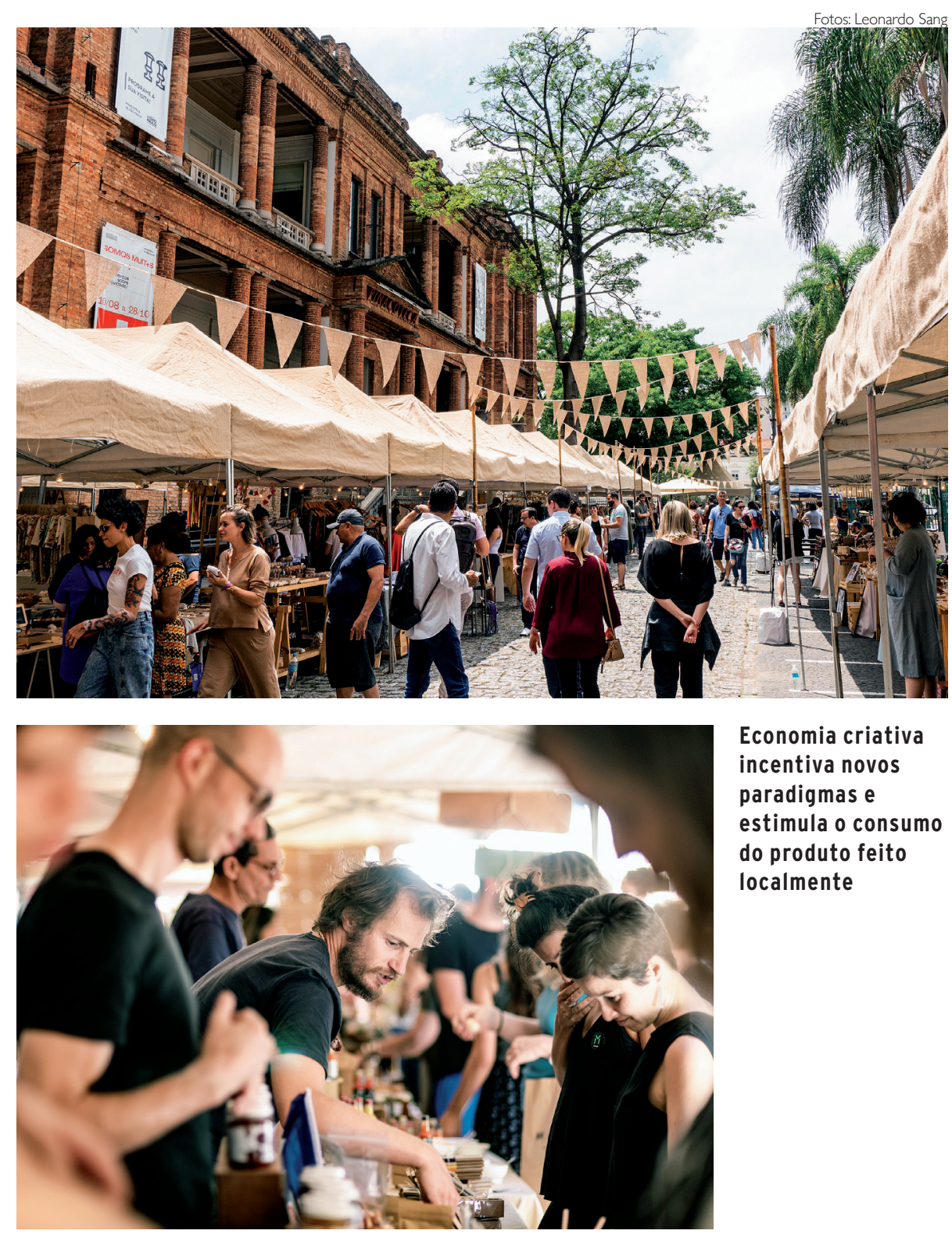

Economia criativa incentiva novos paradigmas $\mathrm{e}$ estimula 0 consumo do produto feito localmente que reúne artesãos e pequenos empreendedores, ressalta o compartilhamento dos saberes como um dos principais valores da criação artesanal e dos negócios que surgem a partir daí.

A economia criativa tem o potencial de abrir oportunidades para diversos nichos de mercado e para a inclusão de diferentes grupos sociais. Um exemplo é o Coletivo TransSol, voltado para o desen- volvimento socioeconômico e psicológico de transexuais e travestis através do ensino de moda, bonecaria e artesanato. $\mathrm{O}$ grupo se formou na Incubadora Pública de Empreendimentos Econômicos Solidários, no bairro do Cambuci, na capital paulista. Para a coordenadora do projeto, Priscila Nunes, o mais importante no TransSol é a possibilidade de dar oportunidades para minorias e educá-las, transformar os seus talentos em uma forma de remuneração. Algo parecido acontece no projeto Ser Âmica, gerido pela artista Nany Pereira e que oferece aulas de cerâmica para adolescentes carentes na Zona Leste da cidade de São Paulo. Segundo ela, hoje, muitos dos jovens que passaram pelo projeto são capazes de se sustentar ou ter um complemento de renda.

PARADIGMA DO CONSUMO Do ponto de vista econômico, o sucesso desses projetos depende, no entanto, de uma mudança nos paradigmas de consumo. É preciso recuperar o consumo local. "Atualmente, a indústria tem que produzir produtos que durem mais porque eles vão viajar por muito tempo. Isso tem que mudar. Você tem que conhecer o fornecedor daquele pão, por exemplo", provoca Rossi. "Já estamos vendo muitas marcas e cadeias de loja se preocupando com isso e conseguindo impactar diferentes nichos de cliente, que não estão inseridos nessa bolha”, complementa.

A possibilidade de alinhar o consumo com o desenvolvimento social e tecnológico é o grande mote da economia criativa. Como explora diferentes frentes - que vão da realização de festas populares, como acontece com o Galo da Madrugada, até o desenvolvimento tecnológico, como acontece com o Porto Digital -, o caminho ainda é longo, mas já traz um impacto considerável na economia nacional.

Lucas Loconte 